\title{
ВІЙСЬКА РОСІЙСЬКОГО ПІВДЕННО-ЗАХІДНОГО ФРОНТУ ПІД ЧАС ВІДСТУПУ У ЛИПНІ 1917 року
}

У статті розглядаються дії російських військ Південно-Західного фронту у ході відступу після прориву німецьких та австро-угорських військ під Тернополем у липні 1917 року на західноукраїнських землях під час Першої світової війни. Простежено участь військ у бойових діях, наводяться приклади звитяжної бойової діяльності окремих військових частин та іiі вплив на результати боїв. Приділено увагу діям дивізій і корпусів. Наведено приклади застосування авіації та кінноти.

Ключові слова: Російська армія, Перша світова війна, кампанія 1917 р., відступ, армія, корпус, дивізія, піхота, кіннота, артилерія, авіація.

Постановка проблеми та ї̈ актуальність. Помітне місце в історії Першої світової війни на українських землях займає бойова діяльність російських військ Південно-Західного фронту під час відступу після Тернопільського прориву німецьких та австро-угорських військ у липні 1917 р. Її грунтовний розгляд дозволяє вивчити внесок військ у результати бойовищ столітньої давнини. Тому вони і надалі цікавлять дослідників.

Аналіз попередніх досліджень $i$ публікацій. Дана тема опрацьовувалася у спеціальних наукових працях. Загальний перебіг бойових дій висвітлив А. М. Зайончковський [1, с. 84]. Коротко дії військ Південно-Західного фронту розглянуто у працях радянських дослідників [3, 13, 19]. Історики російської білої еміграції також вивчали бойові дії літа 1917 р. [4, 9, 14, 18]. Українська історична наука за останні роки зробила помітні кроки у даному напрямі, різноаспектно розкриваючи тогочасні події [5, 6, 17]. В цілому ж історіографія даного питання розкриває переважно бойову діяльність армій i подекуди корпусів, дивізії ж і полки залишаються поза увагою дослідників.

Науменко Андрій Олегович, кандидат історичних наук, старший науковий співробітник, начальник науково-дослідної лабораторії кафедри моральнопсихологічного забезпечення діяльності військ (сил), Національний університет оборони України імені Івана Черняховського, м. Київ.

(C) Науменко А.O., 2018 
Важливий матеріал для дослідження містять мемуари Б. Геруа, Е. Людендорфа, П. Врангеля, Ю. Зубова, Д. Дорошенка та інших $[7,8,10,12,15]$. Загалом даний комплекс джерел дає можливість дослідити бойову роботу військ під час відступу у липні 1917 p.

Мета та завдання статmі. Мета статті полягає у висвітленні діяльності військ Південно-Західного фронту під час відступу у липні 1917 року.

Російський наступ 28 червня (11 липня) 1917 р. на Калуш поставив австро-угорські війська у складне становище. Під загрозою опинилися важливі промислові райони Стрия i Дрогобича. Це сильно вразило німецьке командування. До місця прориву почали зосереджуватися резерви спочатку з Російського, а потім і з Французького фронтів. Цьому сприяла поведінка французького командування та уряду. Поразка грандіозно задуманої квітневої операції і заява про відмову найближчим часом від наступальних операцій розв'язали руки німцям [1, с. 660]. А. Керсновський вказує, що німецьке командування, так би мовити, запрошувалося до перекидання військ 3 Французького фронту на Російський [14, с. 288]. Е. Людендорф писав: „На сході нам належало продовжити бити Росію, наносячи йй все нові й нові удари, щоб розвалити цього колоса." $[15$, с. 479]. Отже, Центральні держави рахувалися $з$ російською потужністю і прагнули вивести іiі з війни.

До ділянки прориву було перекинуто із Західного фронту 11 дивізій і до 5 дивізій було знято з інших ділянок Східного фронту. Ці війська прибули у Галичину після того, як наступ російських 11-ї та 7-ї армій захлинувся. Дві дивізії були відразу ж направлені рятувати III-ю армію на Лімницю, а інші направились під Зборів, де утворили на правому фланзі II-ї австро-угорської армії Золочівський загін генерала А. Вінклера. Головнокомандуючий Східним фронтом принц Леопольд Баварський наказав йому перейти у контрнаступ у загальному напрямку на Тернопіль. Золочівський загін було доведено до 12 піхотних дивізій (11 німецьких) і націлено на лівий фланг російської 11-ї армії $[14$, с. $289 ; 19$, с. 359$]$.

Зранку 6 (19) липня противник відкрив артилерійський вогонь по розташуванню V-го Сибірського, XVII-го і V-го армійських корпусів і майже одночасно його піхота повела атаку [6, с. 132]. 
За даними А. Керсновського, вогонь вели 600 гармат i 180 мінометів. Удар Золочівського загону відбувся по XXV-му армійському корпусові, що не виявив стійкості. Розпропагована 6-а Гренадерська дивізія збунтувалася, і весь корпус кинувся 3 фронту. Один із полків 6-ї гренадерської дивізії - 607-й Млинівський тікав одним з перших. 3 усієї дивізії вдалося зібрати 200 чоловік. 3 XXV-го корпусу у полон потрапило 85 офіцерів, 2900 солдатів і 10 гармат. Німці, за їхнім же визнанням, як вказує А. Керсновський, були «приголомшені» цим успіхом. Атаку на сусідній праворуч V-й Сибірський корпус відбила 6-а Сибірська стрілецька дивізія, німці ж перенесли удар на південь [14, с. 289].

За свідченням тодішнього начальника штабу 11-ї армії генерал-майора Б. В. Геруа, кинуті на допомогу резерви, корпусні, а потім і армійські, не змогли відновити становище. Вони швидко втягувалися у відступ, який нестримно розширювався і перетворювався у стихійний. Противник переніс вогонь на тил i резерви. Піхота, втративши свою традиційну стійкість, виявилася нездатною ні на контрудар, ні на імпровізацію оборони у ближчому тилу, щоб затягнути прорив. Тільки вдалі дії російської артилерії стримували натиск противника [8, с. 201]. Противника стримували тільки кіннота та окремі, що не втратили боєздатності, піхотні частини [13, с. 115].

До кінця дня було прорвано фронт 11-ї російської армії на ділянці у 20 км шириною і 15 км глибиною [19, с. 361]. Скориставшись цією «хвірткою», що відкрилася у фронті, німці увійшли у відкритий проміжок [8, с. 200].

Контрудар надто стривожив Ставку. 7 (20) липня О. Брусилов вимагав від О. Гутора: „,... не тільки вжити всіх заходів для того, щоб зупинити наступ противника, але енергійно перейти у контратаку і відновити положення". Відхід 7-ї армії не допускався, розвиток успіху противника не міг загрожувати Тернополю. Висловлювалося сподівання, що знайдуться „доблесні і вірні обов'язкові” полки, які затримають просування німців $[19$, с. $361 ; 1$, с. 80]. Проте відхід XXV-го корпусу потягнув за собою і XVII-й. Прорив нестримно розширювався i поглиблювався. Генерал І. Г. Ерделі кинув 7 (20) липня у контратаку XLIX-й корпус, але він був відбитий. Услід за ним відійшли I-й гвардійський i V-й армійський корпуси [14, с. 289]. 
Прикладом дій вірних частин є бої, які вела гвардія 7-8 (20-21) липня. Їх перебіг викладено у статті Ю. Зубова [12]. Відзначимо лише, що підсумки їх були досить вагомі для 8-ї армії. Німці завдали контрудар поблизу Зборова, намагаючись оточити іï. Гвардії було наказано ліквідувати прорив і прикрити відступ. Гвардійці 48 годин утримували свої позиції і неодноразово переходили у контратаки. Завдяки їх героїзмові, особливо Преображенського полку полковника Кутєпова, що зазнав великих втрат, оточення вдалося уникнути [21, с. 49]. Втрати 2-го батальйону - до 600 солдатів, 3-го - до 400, 1-й і 4-й батальйони бл. 300. Також полк втратив 15 офіцерів [12].

Південно-Західний фронт мав у своєму складі авіацію, яку Б. Геруа вважає, однак, нечисленною [8, с. 201]. Тим не менше російські льотчики робили все можливе, щоб полегшити відступ своїх військ. Увечері 7 (20) липня ескадрилья німецьких i австрійських літаків здійснила наліт на Тернопіль і летовище. На перехоплення іiі піднялося лише п'ять російських винищувачів. Три 3 них були 3 7-го авіазагону. Першим керував командир загону корнет Ю. Гільшер. Двоє інших були - поручик Макейонок і прапорщик Янченко. У бою Ю. Гільшер героїчно загинув, здобувши свою п'яту i останню перемогу. Так авіатори, вступивши у бій проти 16 літаків, зірвали плани німецької авіації. Ворожі бомби, впавши в околицях летовища, не вчинили ніякої шкоди місту і літакам [2, с. 45].

Активно діяли бомбардувальники літаків „Ілля Муромець”. Підполковник Башко підняв у повітря весь загін - 7 літаків, а 3 ними йшли також 26 винищувачів - всього 33 апарати. Учасники подій свідчать: „Про це давно мріяли, але зробили пізно. ... зрозуміло, що до такої ескадри не зміг би наблизитися ні один німецький винищувач, ... . Першими падали бомби на війська противника, ..., серед яких піднялася паніка. Обравши полосу фронту у 30 верст довжиною і 15 у глибину - знищили на ній все, що мало хоч якесь воєнне значення. ...” [16, с. 291]. Такі вдалі дії авіації сприяли російським військам, але вони лише відступали i внесок льотчиків тільки на короткий час забезпечив їх безладний відступ.

8 (21) липня командуючого фронтом генерала О. Є. Гутора усунено з посади і замінено Л. Г. Корніловим. Він визначив 11-й і 
7-й арміям відходити на Серет - 3 Бурканова і Монастириськи. XXXIV-й армійський корпус мав заповнити розрив між ними $[14$, с. 290]. Новий головнокомандувач фронту вирішив застосуванням жорстких заходів врятувати становище. Але i такий спосіб керівництва результатів не дав. Обговорення бойових наказів на мітингах i y комітетах продовжувалося. Багато частин відмовлялися їх виконувати [6, с. 132]. Щодо подальшого ведення операцій, Корнілов зупинився на єдино вірному рішенні, що напрошувалося само собою з самого початку катастрофи, відвести 7-у і правий фланг 8-ї армії на схід.

9 (22) липня противник залишив у спокої 11-у армію i спрямував свій удар на 7-у. Зранку три його роти з кулеметами рушили вздовж обох берегів Стрипи на південь і примусили до втечі 126-у і 2-у фінляндські дивізії. На позиції залишилися лише офіцери і унтер-офіцери та кілька солдатів [1, с. 79]. Офіцери цих дивізій - 300 чоловік - пішли самі проти 10000 противника. Ніхто 3 них не повернувся [14, с. 291]. Подібних ганебних випадків за всю війну було в Російській армії небагато. М. Головін вказує, що вся піхота тікала, заповнюючи своїми юрбами дезертирів всі шляхи. Якою була їх кількість, свідчить те, що один ударний батальйон у тилу 11-ї армії затримав за одну ніч в околицях м. Волочиська 12000 дезертирів. Ці дезертири направлялися більшовиками $\mathrm{i}$ чинили на своєму шляху неймовірні звірства: вбивали офіцерів, грабували місцевих мешканців, гвалтували жінок і дітей під більшовицький заклик „Ріжь буржуя!” [9, с. 472-473].

Разом $з$ тим Ставка хвалила поведінку 194-ї піхотної дивізії (773-й Зайсанський, 774-й Байкальський (Куртанський), Памирський, Кустанайський піхотні полки) [11, с. 508]. У 7-й армії генерал Л. М. Белькович направив XXXIV-й корпус на праве крило, щоб заповнити розрив, але А. Вінклер випередив його, вигравши його правий фланг. Одночасно XXII-й корпус самочинно пішов 3 фронту. Правий фланг 8-ї армії - III-й Кавказький корпус відійшов на лінію Носів-Больчівці [1, с. 79]. Командуючий 8-ю армією генерал В. А. Черемісов наказав відступати на меридіан Станислава і рушив на підсилення флангу армії XII-й армійський корпус. 3 Північного фронту у Буковину було переведене управління 1-ї армії генерала Г. М. Ванновського. 
Нова 1-а армія об'єднала лівофлангові корпуси 8-ї- XI-й, XXIII-й і XVIII-й, що залишалися у Буковинських Карпатах. У 8-й армії залишалися XII-й армійський, III-й Кавказький, XXXIII-й і XVI-й армійські корпуси і II-й кінний корпус [14, с. 291].

В нічь на 10 (23) липня правофлангові корпуси 7-ї армії відійшли на лінію Микулинці-Бурканів, а VII-й Сибірський i XXII-й армійський, почали, згідно 3 наказом, відхід на лінію Бурканів-Олеша-Монастириська. У зв'язку з відходом 7-ї армії і на виконання директиви фронту 8-а армія почала відхід на лінію Монастириська-Угорники-Надвірна-Тартарів. Правий i лівий фланги фронту залишалися на місці [1, с. 79-80].

10 (23) липня противник знов перейшов у наступ проти лівого флангу 11-ї армії на фронті Мишківці-Микулинці i, збивши частини V-го армійського корпусу і Забайкальської козачої дивізії, форсував Серет. Відновити положення не вдалося [1, с. 81]. Вінклер вдарив на Тернопіль, але був відбитий російським I-м гвардійським корпусом. Хоробро билися полки 1-ї і 2-ї гвардійських піхотних дивізій. Відзначилися 3-й і 5-й батальйони самокатників, що знищили 143-й німецький піхотний полк [14, с. 292].

У середині дня противник перейшов у наступ також між Стрипою і Серетом. Протягом певного часу XXXIV-й корпус i 104-a дивізія стримували противника, але, знесилені масовим дезертирством, відійшли на лінію Островчик-Брикуля, що спричинило відхід лівофлангових корпусів 7-ї армії на лінію Брикуля-Олеша-Монастириська. 8-a армія далі відходила на лінію Монастириська-Угринів-Надвірна-Тартарів [1, с. 81].

Зранку 11 (24) липня противник почав розвивати наступ на фронті Мишківці-Микулинці і потіснив російські війська далі на схід. Пізно ввечері лівофлангові корпуси 11-ї армії відійшли під тиском противника на лінію Плотич - р. Гнізна-Теребовля.

Між Серетом і Стрипою противник протягом дня вів наступ, i на вечір правий фланг 7-ї армії було відкинуто на лінію БудзанівРоманів-Петликівці. Під час бою численні частини уходили у тил, кидаючи свої позиції. Західніше Стрипи противник прорвав розташування XXII-го корпусу поблизу Олеші i до ночі лівофлангові корпуси 7-ї армії відійшли назад, вирівнявшись 3 11-ю армією на лінії Петликівці-Озеряни-Бариш, 8-a армія відходила під прикриттям арієргардів на лінію Бариш-НижнівМладотинь [1, с. 81-82]. 
Пізно ввечері 11 (24) липня командувач Південно-Західним фронтом повідомляв у Ставку, що обстановка на фронті 7-ї армії, у зв'язку з відходом військ, що посилювався, і розкладом у них, виключає можливість міцно закріпитися на зайнятій позиції і не дає впевненості у швидкому припиненні наступу противника попри вжиті заходи [6, с. 132].

Наступ противника розвивався. 12 (25) липня німці зайняли Тернопіль. Це створило загрозу флангові і тилу 7-ї та 8-ї армій, які змушені були розпочати відхід. Зранку противник потіснив росіян на північ і на південь від Теребовлі i, прорвавши позиції, став розвивати успіх у північно-східному напрямку. Російські контратаки зазвичай успіху не мали, i війська почали відкочуватися на схід. 13 (26) липня противник активних дій не вів. Війська завершали відхід і облаштовувалися на позиціях [1, c. 83].

Самовіддано працювала у ці дні кіннота. Про іï бойову роботу свідчать дії 7-ї кінної дивізії генерала П. М. Врангеля (7-й Кінбурнський драгунський, 7-й Ольвіопольський уланський, 7-й Білоруський гусарський, 11-й Донський козачий полки). 10 (23) липня Врангель прийняв командування Зводним кінним корпусом, до складу якого увійшли і 7-а кінна та 3-я Кавказька козача дивізії [7; 11, с. 92]. Корпус мав діяти у зтик 7-ї і 8-ї армій, прикриваючи їх відхід і забезпечуючи фланги. Протягом дня корпус утримував свої позиції. Проте близько 2-х годин дня німці відтіснили Кінбурнських драгунів, і вже загрожували розбити фланг корпусу. Тоді Врангель наказав дивізіону Кінбурнців зупинити противника у кінному строю. Драгуни під проводом ротмістра Стаценка блискучою атакою вибили противника, захопивши кілька десятків полонених і кулемет. Становище було відновлено. У подальшому кінний корпус безперервно вів арієргардний бій. Так, бригада кінноти противника рушила 3 метою охопити правий фланг корпусу у розріз між двома дивізіями. Тоді П. М. Врангель наказав артилерії відкрити швидкий вогонь і пустив дивізію в атаку, якої противник не прийняв і став швидко відходити. Тоді ж для охоплення лівого флангу корпусу, майже у тил, рушила ще одна бригада ворожої кінноти. Вогонь артилерії перенесли на цю колону, а противника атаковано трьома полками. I цього разу ворожа кіннота поспішно 
відійшла. Незабаром Кавказька дивізія перейшла в наступ, збила противника і висунулася на попередні позиції. Протягом дня російські кавалеристи утримувалися на місці, вели перестрілку, противник не наступав. Ці дії кінноти значною мірою сприяли дальшому відступу [7].

Як видно, кіннота не втрачала свого значення на полі бою в умовах відступу, самовіддано прикриваючи відхід піхоти, що вже став безладним. Кінні ж частини зберігали порядок і дисципліну в умовах швидкого розвалу всього Російського фронту i виконували бойові завдання.

Іншим прикладом $є$ дії польських уланів. 11 (24) липня під с. Креховцями відбувся славетний кінний бій, в пам'ять про який полк отримав пізніше почесне найменування Креховецького. Спочатку вони, підтримані П. М. Врангелем, приборкували мародерів з числа вояків розкладених піхотних частин. Протягом 5-6 годин полк здійснив окремими ескадронами шість кінних атак проти баварської піхоти і австрійських драгунів, які не прийняли атаки. Ці хоробрі атаки порівняно нечисленної кінної частини затримали наступ противника настільки, як того вимагали обставини бою. Дії полку відзначив командувач військами фронту генерал Л.Г.ККорнілов. В подальшому улани брали участь у деяких незначних зіткненнях під час відходу до румунського кордону [4, с. 39; 7].

Активно діяв II-й кінний корпус. Промовистим прикладом його діяльності $є$ бойова робота 9-го Київського гусарського полку. 310 (23) по 15 (28) липня полк брав участь у прикритті відходу армій Південно-Захіного фронту у районі ПрислупНадвірна-Бучач-Чортків-Гусятин. Всі шість днів Київські гусари, як і інші полки 9-ї кінної дивізії, рухаючись здовж фронту піхоти, що відходила у безладі, затримувалися там, де противник, не зустрічаючи спротиву, енергійно насідав на охоплену панікою піхоту. Тоді гусари зав'язували 3 противником бій, примушуючи його розгортатися i, виграючи таким чином час, давали можливість піхотним частинам якщо не затримуватися для бою, на що вони були остаточно нездатні, то хоча б для того, щоб перетворити їх безладний відхід у планомірний відступ. Часто однієї появи доброї кінної частини серед піхотинців, що тікали і відходили, було досить, щоб до цих частин поверталися втрачені 
ними спокій і певне почуття обов'язку. А 14 (27) липня Київський полк під проводом полковника Фомицького, стримуючи натиск противника, вів впертий і тяжкий бій з переважаючими силами австрійців поблизу сіл Васильківці і Копичинці, а потім 3 військами перейшов на російську територію [18, с. 14].

Самовіддано діяла Заамурська кінна бригада генерала О. Карницького спільно 3 Іркутськими гусарами i Архангелогородськими драгунами. Ці частини склали Зводну кінну дивізію генерала Свєчина, також у II-му кінному корпусі. Особливо важкі бої вони витримали 13 (26)-14 (27) липня. У бою під Швейківцями відзначаються вмілі дії командирів частин, а також окремих підрозділів. Штабс-капітан Румянцев силою 25-ї кінної батареї відбив атаку німецької кінноти і двома гарматами підтримав кінну атаку на німців Іркутських гусарів і Архангелогородських драгунів. Згодом до атаки долучився 1-й Заамурський кінний полк. Окремі підрозділи полку прикривали свою батарею, а потім у піших лавах відбивали атаку німецької піхоти, після чого переслідували iї у кінному строю. Наступного дня 2-й Заамурський кінний полк кінними атаками затримав наступ ворожої піхоти і кінноти поблизу Шманьковчиків. Відзначаються дії командира полку полковника Корганова і командира дивізіону підполковника Султан-Гірея. Блискуче діяли 1-й і 3-й ескадрони поручиків Попова та Федорова i 4-й ротмістра Враштіл [20, c. 502-503].

Росіяни продовжували відступ. 14 (27) липня 8-a армія залишила Городенку. 15 (28) липня її правофлангові корпуси XII-й армійський і III-й Кавказький вперто билися в гирлі Збруча 3 армією Ф. Ботмера i вночі відійшли на його лівий берег. Лівофлангові - XXXIII-й і XVI-й билися поблизу Заліщиків і Снятина, стримавши армію К. Крітека у Задністров'ї. Для заповнення розриву між цими двома групами генерал Корнілов направив у центр 8-ї армії кінну групу генерала П. М. Врангеля [14, с. 293]. 3 настанням темряви, згідно з директивою фронту, армії почали відходити на лінію: 11-а і 7-а - Плотич-ХоростківКопичинці-Чортків-Ягольниця, 8-a i 1-a - Ягольниця-ЛатачНезвиська-Коломия-Розтока-Томнатик-Капул. Правий і крайній лівий фланги фронту залишалися на місці.

Німецький контрудар призвів до повного розладу всього Південно-Західного фронту. Російські війська, майже не чинячи 
спротиву, знімалися 3 позицій i йшли на схід. Німецьке командування отримало можливість розвивати свій успіх далі. Але воно не вжило ніяких заходів у цьому напрямі. Загальний відступ росіян фактично припинився на 15 (28) липня [19, с. 361].

Тільки на окремих ділянках противник ще просувався. Вночі на 21 липня (3 серпня) було залишено Чернівці. Д. Дорошенко наводить короткі спостереження про відступ російських військ із Чернівців: „Незвичайну картину уявляло 3 себе шосе від Чернівців до російського кордону і далі на сотню верст вглиб: відступала мільйонова армія, і здавалось, що це якесь переселення народів. Перша паніка вже вляглася, частини армії були сяк-так організовані наново, відступ прикривали більш надійні, тверді полки, котрі відходили з боєм. Та й наступ ворога вже значно ослаб." [10, с. 145]. Б. Геруа так оцінює стан військ після відступу: „Як не велика була поразка, все ж вона не перетворилася у повну катастрофу, завдяки частково прийняттю командуванням швидких заходів, частково тому, що противник, натискючи все більше і більше на південь, дозволив 11-й і 7-й арміям оправитися і зачепитися за новий рубіж на схід від Тернополя. ... В решті решт, до середини липня, після тижня тривожних боїв, ми зупинилися на меридіані р. Збруч, нашого попереднього державного кордону." [8, с. 203].

Після цього на Південно-Західному фронті настало затишшя. Бойові дії не велися. Армії закріпилися на рубежі Броди, Збараж, Гримайлів, Боян, східніше Кімполунга [19, с. 361]. Проте німці самі припинили наступ у Галичині і Буковині і перенесли зусилля у Прибалтику [15, с. 479].

Висновки. Таким чином, менш ніж за півмісяця російські війська змушені були відступити, залишивши майже всю Галичину. Всі попередні успіхи у війні зводилися нанівець. Проте значно було полегшено становище союзників, оскільки з фронту на Заході було відведено значну частину сил на схід для боротьби 3 росіянами. Навіть підірвана революційними змінами російська армія змушувала противника рахуватися з собою.

Командування фронту робило все можливе для впорядкування дій військ у відступі, проте навіть жорсткі заходи не давали бажаного результату. Звинувачувати російських генералів у неспроможності приймати вірні рішення було б невірно. Війська масово відмовлялися виконувати накази, а їх нестримний відхід у тил зупинити було неможливо. 
Разом 3 тим перебіг відступу військ Південно-Західного фронту показав, що навіть в умовах революційного розвалу поряд із частинами, які зрадили військовому обов'язкові, залишалася досить значна кількість і таких, що продовжували битися. Слід особливо відмітити артилерію, кінноту та авіацію, які зберігали порядок i дисципліну та виконували бойові накази. Їх безумовною заслугою стало те, що вони у несприятливих умовах змогли прикрити безладний відступ. Саме завдяки відчайдушним діям цих та інших вірних частин війська Південно-Західного фронту було врятовано від остаточного розгрому.

1. Стратегический очерк войны 1914-1918 гг. Ч. 7. $\begin{array}{llll}\text { Кампания } 1917 \text { г. Составил } & \text { А. М. Зайончковский.- }\end{array}$ M. 1923 Режим доступу: http://www.grwar.ru/library/Strateg _Essay_7/index.html.

2. Аверченко С. Юрий Гильшер - один из первых асов России // Военно-исторический журнал.- 2001. № 8. C. $38-47$;

3. Агеев А., Вержхховский Д., Виноградов В., Глухов В., Криницын Ф., Ростунов И., Соколов Ю., Строков А. История первой мировой войны 1914-1918 гг. / Под редакцией доктора исторических наук И. И. Ростунова. Москва: Наука, 1975. - 712 с.

4. Бем де Косбан В. Польские Уланы в рядах Российской Императорской Армии (Историческая справка) // Военная быль. - 1967. - № 84. - С. 37-40.

5. Велика війна 1914 - 1918 рp. і Україна. У двох книгах. Книга 1. Історичні нариси. - К.: ТОВ «Видавництво „КЛІО”», 2014. - 783 c.

6. Велика війна 1914 - 1918 рр. і Україна: У двох книгах. - Книга 2: Мовою документів і свідчень. - К.: ТОВ «Видавництво „КЛІО”», 2015. - 800 с.

7. Врангель П. Южный фронт (ноябрь 1916 г. ноябрь 1920 г.). Часть I // Воспоминания. - М.: ТЕРPА, 1992. $-544 \mathrm{c}$.

8. Геруа Б. Воспоминания о моей жизни. Т.2, Париж, 1969.

9. Головин Н. Россия в Первой мировой войне / Николай Головин. - М.: Вече, 2006. - 528 c.

10.Дорошенко Д. Мої спомини про недавнє минуле (1914-1920 роки): Науково-популярне видання. - К.: Темпора, 2007. $-632 \mathrm{c}$.

11.Залесский $K$. Первая мировая война. Биографический энциклопедический словарь - М.: Вече, 2000. - 576 с. 
12.Зубов Ю. Последний штыковой бой преображенцев на юго-западном фронте // Часовой. - № 13-14, 1929, Париж Режим доступу: http://www.grwar.ru/library/Zuboff/ index.html.

13. Кавтарадзе А. Июньское наступление русской армии в 1917 году // Военно-исторический журнал. - 1967. № 5. - С. 110-117.

14.Керсновский А. История Русской Армии. - М.: Воениздат, 1994. - Т. 4. - 338 с.

15.Людендорф Э. Мои воспоминания о войне 19141918 гг. - М.: АСТ. Мн.: Харвест, 2005. - 800 с.

16.Никольский C. «Муромцы» в бою: Подвиги русских авиаторов / Сергей и Михаил Никольские. - М.: Єксмо: Яуза, 2010. - 384 с.

17.Периа світова війна 1914 - 1918 рр. і Україна. Українські землі у центрі цивілізаційної кризи / Упоряд. О. П. Реєнт. - К.: ТОВ «Видавництво Кліо», 2015. - 64 с.

18.Протопопов H. Киевские гусары в войну 19141917 гг. // Военная быль. - 1973. - № 123. - с. 10-23.

19.Ростунов И. Русский фронт Первой мировой войны. - М.: Издательство «Наука», 1976. - 387 с.

20.Русская кавалерия в Первой мировой войне / составл., предисл., коммнтарии д. и. н. С. В. Волков. - М.: АЙРИС-пресс, 2016. - 528 с.

21.Тихомиров B., Чапкевич E. Русская гвардия в Первую мировую войну // Вопросы истории. - 2000. № 9. - С. 32-51.

Надійшла до редколегії 22.05.2018 р.

\section{Naumenko A.O. \\ FORCES OF RUSSIAN SOUTH-WEST FROUNTING LINE DURING STEPBACK IN JULY 1917}

The article contains the information about the actions of the Russian troops of the South-west front line during the stepback after the breakthrough operation of German and Austro-Hungarian troops near Ternopil in July 1917 in Western Ukraine during the First World War. The participation of troops is analyzed in battles; there are examples of victorious combat activity of individual military units and their influence on the results of battles. Also the attention is paid to the actions of divisions and corps. The examples of aviation and cavalry are provided.

Keywords: Russian troops, First World War, 1917 campaign, stepback, troops, corps, division, army, cavalry, artillery, aviation. 